\title{
Compulsory Joinder of Classes Under Rule 19
}

\author{
Thomas D. Stoddard $\dagger$
}

What happens when a procedural phantom ${ }^{1}$ meets a freak from birth?2 ${ }^{2}$ The Federal Rules of Civil Procedure have adopted both the rules of necessary parties (Rule 19(a)) and class actions (Rule 23) from equity practice. Rule 19(a) requires the joinder of persons whose absence creates a risk of an incomplete or unjust judgment. ${ }^{3}$ Rule 23 allows one or more members to represent an entire class of individuals under certain circumstances. ${ }^{4}$ The inter-

$\dagger$ B.A. 1987, Swarthmore College; J.D. Candidate 1992, The University of Chicago.

1 The indispensable party. See Geoffrey C. Hazard, Jr., Indispensable Party: The Historical Origin of a Procedural Phantom, 61 Colum L Rev 1254, 1254 (1961); FRCP 19(b).

2 The class action. See Stephen C. Yeazell, Group Litigation and Social Context: Toward a History of the Class Action, 77 Colum L Rev 866, 866 (1977). See also Zechariah Chafee, Jr., Some Problems of Equity 200 (Michigan, 1950) ("The situation is so tangled and bewildering that I sometimes wonder whether the world would be any the worse off if the class-suit device had been left buried in the learned obscurity of Calvert on Parties to Suit in Equity.").

s FRCP 19(a) states:

(a) Persons to Be Joined if Feasible. A person who is subject to service of process and whose joinder will not deprive the court of jurisdiction over the subject matter of the action shall be joined as a party in the action if (1) in the person's absence complete relief cannot be accorded among those already parties, or (2) the person claims an interest relating to the subject of the action and is so situated that the disposition of the action in the person's absence may (i) as a practical matter impair or impede the person's ability to protect that interest or (ii) leave any of the persons already parties subject to a substantial risk of incurring double, multiple, or otherwise inconsistent obligations by reason of the claimed interest. If the person has not been so joined, the court shall order that the person be made a party. If the person should join as a plaintiff but refuses to do so, the person may be made a defendant, or, in a proper case, an involuntary plaintiff. If the joined party objects to venue and joinder of that party would render the venue of the action improper, that party shall be dismissed from the action.

- FRCP 23 states:

(a) Prerequisites to a Class Action. One or more members of a class may sue or be sued as representative parties on behalf of all only if (1) the class is so numerous that joinder of all members is impracticable, (2) there are questions of law or fact common to the class, (3) the claims or defenses of the representative parties are typical of the claims or defenses of the class, and (4) the representative party will fairly and adequately protect the interests of the class.

(b) Class Actions Maintainable. An action may be maintained as a class action if the prerequisites of subdivision (a) are satisfied, and in addition: 
play between these two monsters, however, remains unclear. Can a class be a person necessary for a just adjudication of a dispute between litigants already before the court? At first glance the answer is no. Rule 19(d), "Exception of Class Actions," states that the entire Rule 19 is "subject to the provisions of Rule 23." A closer look, however, reveals that Rule $19(\mathrm{~d})$ is not an obstacle to the joinder of a "necessary class."

Few courts have confronted this question head on. In Shimkus $v$ Gersten Companies, ${ }^{6}$ the Ninth Circuit rejected the position that Rule 19(d) uniformly excludes classes from joinder. Instead, the Ninth Circuit held that Rule 19(d) "allows joinder [of classes] to the extent its use does not conflict with Rule 23's provisions." In contrast, several district courts have explicitly or implicitly interpreted Rule 19 to preclude the consideration of classes as necessary parties. ${ }^{8}$ These courts apparently view Rule $19(\mathrm{~d})$ as a boundary dividing mutually exclusive mechanisms.

(1) the prosecution of separate actions by or against individual members of the class would create a risk of

(A) inconsistent or varying adjudications with respect to individual members of the class which would establish incompatible standards of conduct for the party opposing the class, or

(B) adjudications with respect to individual members of the class which would as a practical matter be dispositive of the interests of the other members not parties to the adjudications or substantially impair or impede their ability to protect their interests; or

(2) the party opposing the class has acted or refused to act on grounds generally applicable to the class, thereby making appropriate final injunctive relief or corresponding declaratory relief with respect to the class as a whole; or

(3) the court finds that the questions of law or fact common to the members of the class predominate over any questions affecting only individual members, and that a class action is superior to other available methods for the fair and efficient adjudication of the controversy. The matters pertinent to the findings include: (A) the interest of members of the class in individually controlling the prosecution or defense of separate actions; (B) the extent and nature of any litigation concerning the controversy already commenced by or against members of the class; (C) the desirability or undesirability of concentrating the litigation of the claims in the particular forum; (D) the difficulties likely to be encountered in the management of a class action.

B FRCP 19(d).

- 816 F2d 1318 (9th Cir 1987).

I Id at 1321 (emphasis in original). The court found joinder of non-African American minorities desirable in this case, and remanded for a determination of which other minority classes should be joined. Id at 1322. Although Shimkus and other courts employed the appellation "black" to refer to the racial group involved in the litigation, this Comment uses more contemporary language.

${ }^{8}$ See Thompson v Board of Educ. of Romeo Community Schools, 71 FRD 398, 412 (W D Mich 1976) (stating that the party joinder rules "concern separate situations"), rev'd on other grounds, 709 F2d 1200 (6th Cir 1983); LCC Corp. v PBGC, 94 FRD 15 (E D Mo 1980); Hastings-Murtagh v Texas Air Corp., 119 FRD 450 (S D Fla 1988); Spirit v Teachers Insurance and Annuity Association of America, 416 F Supp 1019 (S D NY 1976). See also Jeffries $v$ Georgia Residential Finance Authority, 678 F2d 919, 928-29 (11th Cir 1982) (class 
This Comment argues that allowing for the joinder of necessary classes would facilitate the protection of third parties and the efficient and equitable resolution of disputes. While the Rules already contemplate a number of ways in which the interests of such third parties may be protected, ${ }^{9}$ these mechanisms are imperfect. Joinder of necessary classes provides a critical layer of additional protection.

Sections I and II of this Comment outline the nature of the relationship between Rules 19 and 23 and discuss illustrative cases. Section III argues that the history of, and the policies underlying, the joinder rules support the idea that absent classes that satisfy the standards of Rule 19 may be joined. Section IV discusses some limitations on and possible objections to the necessary class. The Comment concludes that Rule 19(d) is not a bar to the joinder of necessary classes.

\section{The Relationship Between Rule 19 and Rule 23}

\section{A. Overview of the Rules}

Rule 19(a) provides for the joinder of necessary parties. Three factors commonly determine whether a party is necessary under Rule 19(a). A party is necessary if: (1) without her, the court cannot grant complete relief to the original parties; (2) any relief granted in her absence would expose the original parties to the risk of multiple or otherwise inconsistent obligations; or (3) the relief, if granted, would impair the necessary party's own ability to defend a related interest. ${ }^{10}$ The first situation rarely occurs. ${ }^{11}$ If a necessary party is absent from a suit, the defendant can move under Rule 12(b)(7) to dismiss the claim. ${ }^{12}$ The court also may raise the issue

of tenant plaintiffs sought to avoid joining class of landlords by relying on Rule 19(d) exception, but court did not reach the issue because absent landlords were not necessary to the action).

- Among the tools presently available to protect the interests of third parties are intervention of right under Rule 24, notice requirements, consolidation of multiple actions, fairness hearings before court approval of consent decrees, and narrowing the relief available to plaintiffs.

10 FRCP 19(a).

12 See Richard D. Freer, Rethinking Compulsory Joinder: A Proposal to Restructure Federal Rule 19, 60 NYU L Rev 1061, 1081 (1985).

12 FRCP 12(b) provides:

Every defense, in law or fact, to a claim for relief in any pleading . . . shall be asserted in the responsive pleading thereto . . . except that the following defenses may at the option of the pleader be made by motion: . . . (7) failure to join a party under Rule 19. 
on its own motion. ${ }^{13}$ If a necessary party cannot be joined, the court may dismiss the action if it cannot proceed in good conscience without him. ${ }^{14}$ While necessary parties are typically joined as defendants, the court may also join them as involuntary plaintiffs. ${ }^{16}$

Under Rule 23, class actions must meet four prerequisites: (1) the members of the class are too numerous to join individually; (2) there are questions of law or fact that are common to the class; (3) the claims and defenses of the class representatives are typical of those of the entire class; and (4) the class representatives can fairly represent the entire class. ${ }^{16}$ Furthermore, Rule 23(b) requires a class to qualify as one of three types: (1) a mandatory class; (2) a class seeking injunctive relief; or (3) a class where common questions of law or fact predominate. ${ }^{17}$ Plaintiffs as a class may join together or a plaintiff may sue defendants as a class. ${ }^{18}$

\section{B. A Triangular Lawsuit}

The problem of the necessary class typically arises when a plaintiff, $P$, commences suit against a defendant, $D$, seeking a remedy that may conflict with the interests of $C$, a large number of absentees who are unaware of the action or who are too unsophisticated to intervene. ${ }^{19} \mathrm{C}$ 's interests are often best served when the

13 FRCP 21; Benjamin Kaplan, Continuing. Work of the Civil Committee: 1966 Amendments of the Federal Rules of Civil Procedure (I), 81 Harv L Rev 356, 374 (1967). See Provident Tradesmens Bank v Patterson, 390 US 102, 111 (1968).

14 FRCP 19(b) states:

Determination by Court Whenever Joinder not Feasible. If a person as described in subdivision (a)(1)-(2) hereof cannot be made a party, the court shall determine whether in equity and good conscience the action should proceed among the parties before it, or should be dismissed, the absent person being thus regarded as indispensable. The factors to be considered by the court include: first, to what extent a judgment rendered in the person's absence might be prejudicial to the person or those already parties; second, the extent to which, by protective provisions in the judgment, by the shaping of relief, or other measures, the prejudice can be lessened or avoided; third, whether a judgment rendered in the person's absence will be adequate; fourth, whether the plaintiff will have an adequate remedy if the action is dismissed for nonjoinder.

See also Provident Bank, 390 US 102 (amplifying the balancing test under Rule 19(b)).

16 FRCP 19(a).

16 FRCP 23(a).

27 FRCP 23(b).

18 See FRCP 23(a).

19 This Comment will only address a few examples, but there are many situations that fit this pattern. For illustrations, see cases cited in Douglas Laycock, Consent Decrees Without Consent: The Rights of Nonconsenting Third Parties, 1987 U Chi Legal F 103; LCC Corp., 94 FRD 15 (class of former plan participants not necessary to an action for declaratory judgment by the plan administrator seeking residual assets); Hastings-Murtagh, 119 
relief available to $\mathrm{P}$ and the outcomes available to $\mathrm{D}$ are both limited. Since $\mathrm{C}$ desires an outcome different from that sought by $\mathrm{P}$ or $\mathrm{D}$, it is incorrect to assume that either $\mathrm{P}$ or $\mathrm{D}$ will adequately represent C's interests. ${ }^{20}$

This paradigmatic triangle of interests most often occurs when the plaintiff seeks injunctive relief. ${ }^{21}$ Injunctive relief often imposes new standards of conduct on the parties involved in a lawsuit. These new standards may also affect the interests of other groups not party to the suit, and may, in fact, impair their legal rights. For instance, a civil rights injunction calling for a preference for a particular minority group may reduce the number of opportunities available to other minority groups. ${ }^{22}$ Alternatively, such a plan may be too ambitious and result in "reverse" discrimination against an unrepresented majority ${ }^{23}$ These risks raise questions about the proper interpretation of consent decrees, ${ }^{24}$ the legal consequences of a failure to intervene,,$^{25}$ and the propriety of granting the requested relief. As we shall see, the necessary class concept offers a partial solution to some of these difficulties.

FRD 450 (proposed class of employee-shareholders could not sue the corporation to rescind a merger detrimental to their interests as employees without joining the corporation's nonemployee shareholders); Spirit, 416 F Supp at 1023 (male employees not necessary to a suit by a class of female employees against the administrator of a pension plan); English $v$ Seaboard Coast Line Railroad Co., 465 F2d 43, 47 (5th Cir 1972) (class of white employees or a representative should be joined to an action by African American employees filed against their common employer).

20 To be sure, under Rule 19(a), C would be joined either as a defendant or as an involuntary plaintiff. But this is better than the alternative because neither $P$ nor $D$ represents C's interests sufficiently to justify ignoring $C$ altogether. FRCP 19(a). See also Comment, Defendant Class Actions: The Failure of Rule 23 and a Proposed Solution, 38 UCLA L Rev 223, 264-74 (1990) (proposing to allow defendants to join together on their own initiative, thereby solving a problem partly analogous to the situation considered here).

${ }_{21}$ Professor Freer asserts that the need for an aggressive Rule 19 is strongest in situations where a defendant may be subject to conflicting obligations. See Freer, 60 NYU L Rev at 1090, 1094-96 (cited in note 11). Civil rights class actions are one illustration. See Advisory Committee's Notes on the 1966 Amendment to Rule 23(b)(2).

22 See Shimkus, 816 F2d at 1320.

2s See, for example, Martin v Wilks, 490 US 755 (1989) (white firefighters challenged consent decree reached without their participation on the basis that it resulted in discrimination against them).

34 Compare Laycock, $1987 \mathrm{U}$ Chi Legal F at 121-24 (cited in note 19) (advocating an increased reliance on Rule 19 to protect third parties, even to the extent of joining absent classes), with Larry Kramer, Consent Decrees and the Rights of Third Parties, 87 Mich L Rev 321, 335-38 (1988) (criticizing Laycock and proposing instead that interested third parties should be permitted to enter negotiations through consolidation).

${ }^{23}$ See Martin, 490 US at 765 (failure of white firefighters to intervene in suit by African-American firefighters did not raise "impermissible collateral attack" doctrine when the former later challenged a court-approved affirmative action plan). 
Similar problems arise where the requested relief is money damages. First, like injunctions, money judgments may impose new standards of conduct upon the parties. ${ }^{26}$ Second, a money judgment awarded to one person may expose the defendant to inconsistent obligations when that defendant is subsequently sued by others. ${ }^{27}$ Courts try to avoid these problems by joining union representatives, government officers, and other proxies who resemble class representatives (as defined by Rule 23) and who serve a similar function. ${ }^{28}$ It is only where there is no obvious representative for a group of numerous absentees that we stumble onto a potential lacuna in the rules.

\section{Judicial Treatment of Necessary Classes}

The cases addressing the legitimacy of necessary classes focus on the proper significance to be accorded to section (d) of Rule $19 .{ }^{29}$ Section (d) provides that Rule 19 is "subject to the provisions of Rule 23." The courts are split, however, on whether Rule 19(d) precludes the use of Rule 19 in class actions under Rule 23. Some courts have suggested that the explicit language of section (d) establishes that Rules 19 and 23 are only to operate in mutually exclusive situations. ${ }^{30}$ For example, one court has concluded that the rules concern "separate situations and each has its own requirements for each situation." 31 Other courts interpret the language of section (d) more broadly and hold that Rules 19 and 23 can operate together where they seem to overlap. ${ }^{32}$

${ }^{26}$ See Freer, 60 NYU L Rev at 1089-93 (cited in note 11).

${ }^{27}$ Id.

${ }^{28}$ See Shimkus, 816 F2d 1318; Thompson, 71 FRD 398; Pentland v Dravo Corp., 152 F2d 851 (3d Cir 1945); Alabama v Blue Bird Body Co., 71 FRD 183 (D Ala 1976). See generally Stephen C. Yeazell, From Medieval Group Litigation to the Modern Class Action 18-20, 226-28 (Yale, 1987).

${ }^{29}$ In dicta, the Supreme Court has suggested that Rule 19(d) allows joinder of an absent class, but the context is too weak to justify a strong inference either way. In Illinois Brick Co. $v$ Illinois, 431 US 720 (1977), an antitrust suit, the Court dismissed the claims of all but those plaintiffs who had purchased directly from the manufacturer, but stated that:

Where, as would often be the case, the potential number of claimants at a particular level of distribution are so numerous that joinder of all is impracticable, a representative presumably would have to be found to bring them into the action as a class. Id at 739 (citing FRCP 19(d)).

Only the Shimkus court has referred explicitly to Rule 19(d) when compelling joinder of a class under Rule 19. Shimkus, 816 F2d at 1321. But see Blue Bird Body Co., 71 FRD at 187 (relying on Rule 19 to justify the standing of a class representative).

so Thompson, 71 FRD 398.

si Id at 412 .

32 Shimkus, 816 F2d 1318; Blue Bird Body Co., 71 FRD 183; English, 465 F2d 43. 
The Rules Advisory Committee added section (d) to Rule 19 in 1966 as part of its sweeping revision of the Federal Rules of Civil Procedure governing necessary parties, intervention, and class actions. ${ }^{33}$ The Advisory Committee sought not only to correct technical difficulties in the language and application of the rules, but also to impress upon the rules a more practical, policy-driven approach. ${ }^{34}$ Before 1966, the interplay between Rule 19 and Rule 23 was treated entirely in a prefatory phrase conditioning the first sentence of Rule 19(a). ${ }^{35}$ The Advisory Committee offered no explanation for giving this caveat its own section. ${ }^{36}$ However, by adding section (d) and giving it the subheading, "Exception of Class Actions," the drafters seemed to suggest that Rules 19 and 23 were to govern mutually exclusive situations.

The court in Thompson $v$ Board of Education of Romeo Community Schools, ${ }^{37}$ a class action against several school boards, took this position. Although Thompson concerned the scope of permissive joinder under Rule $20,^{38}$ the court relied on Rule 19(d) to support its analysis. ${ }^{39}$ The Thompson court focused on the explicit language of the caption, "Exception of Class Actions." Specifically, the court asserted that the caption expressly established that Rule 19 is displaced by Rule 23 in the context of class actions. ${ }^{40}$ The court then argued that permissive joinder under Rule 20 was also precluded by Rule 23, even though Rule 20 did not expressly establish as much. The court concluded that "Rule 20 and Rule 23 concern separate situations and each has its own requirements for

\footnotetext{
as See Kaplan, 81 Harv L Rev at 356 (cited in note 13). See also Sherman L. Cohn, The New Federal Rules of Civil Procedure, 54 Georgetown L J 1204, 1204 (1966).

"Kaplan, 81 Harv L Rev at $365 \mathrm{n} 34$ (cited in note 13) ("Thoughtful judges, following the older equity tradition, have indeed often considered the question of joinder to be 'entirely practical'.").

38 Before the 1966 amendments, FRCP 19(a) stated:

(a) Necessary Joinder. Subject to the provisions of Rule 23 and of subdivision (b) of this rule, persons having a joint interest shall be made parties and be joined on the same side as plaintiffs or defendants. When a person who should join as a plaintiff refuses to do so, he may be made a defendant or, in proper cases, an involuntary plaintiff.

See Proposed Amendments to Rules of Civil Procedure for the United States District Courts, 39 FRD 69, 87 (1966).

ss The Advisory Committee Note to FRCP 19(d) simply says that "[S]ubdivision (d) repeats the exception contained in the first clause of the predecessor subdivision (a)." See Proposed Amendments, $39 \mathrm{FRD}$ at 94.

s7 71 FRD 398 (W D Mich 1976).

ss Rule 20 defines the boundaries of permissible joinder by specifying who may be a proper party.

39 Thompson, 71 FRD at 412 .

10 Id.
} 
each situation." By basing its conclusions about Rule 20 on inferences drawn from Rule 19(d), the court implicitly assumed that Rule 19 (d) is an even stronger example of a case where the Rules contemplate separate situations and do not interact.

In part, Thompson manifests the courts' general hesitation to adapt the geometry of litigation to meet the needs of absentees. ${ }^{41}$ This hesitation is based generally on the belief that the interests of absentee classes are either (1) insubstantial, (2) adequately represented by the litigants already before the court, or (3) sufficiently protected by the opportunity to intervene on their own initiative. ${ }^{42}$ Even where compulsory joinder of an interested class is feasible, some courts have found a "public rights exception." This exception allows the court to deny the joinder of private third parties as necessary in suits by plaintiffs seeking to vindicate public rights. ${ }^{43}$

41 See, for example, LCC Corp., 94 FRD at 17 (a class of former plan participants not necessary to an action for declaratory judgment by the plan administrator seeking residual assets); Hastings-Murtagh, 119 FRD at 458 (proposed class of employee-shareholders could not sue the corporation to rescind a merger detrimental to their interests as employees without joining the corporation's non-employee shareholders).

42 See, for example, Eldredge v Carpenters 46, 440 F Supp 506, 527 (N D Cal 1977) (order compelling joinder of numerous indispensable absentees), later proceeding, 83 FRD 136 (N D Cal 1979) (dismissing action because plaintiff failed to adequately join indispensable parties), rev'd, 662 F2d 534, 538 (9th Cir 1981) (absentees not indispensable); Pentland, 152 F2d at 856 (availability of intervention under Rule 24(a)); Mikulay Co. $v$ Urban Mass Transportation Society, 90 FRD 250 (D DC 1980) (federal agency defendants would protect interest of absent city); Jeffries, 678 F2d 919 (absentee landlord lacked sufficient interest); Northern Alaska Envtl. Center v Hodel, 802 F2d 466, 469 (9th Cir 1986) (miners lacked sufficient legal entitlement in regulatory procedures); Drexel Burnham Lambert, Inc. v Warner, 665 F Supp 1549 (Fla 1987) (employees not indispensable to action by customer against firm because interest insubstantial and defended by firm).

In Eldredge, two female apprentice carpenters brought sex discrimination claims against the Joint Apprenticeship Training Committee (JATC). The district court found that the JATC did not represent the 4,500 employers and 60 unions, and that these absentees had a significant interest in the controversy because a judgment against the JATC would directly increase their hiring costs. Eldredge, $440 \mathrm{~F}$ Supp at 523. As the court stated:

The only alternatives appear to be certification of defendant classes or joinder of contractor associations in lieu of individual employer members .... That either of these alternatives can provide a feasible and adequate solution to the problems raised ... is open to serious question. The former would raise a host of questions under Rule 23, while the latter would raise further questions under Rule 19 as to whether individual employers and union locals remain indispensable parties despite the joinder of their representatives.

Id at 526-27.

Eldredge is unlike most Rule 19(b) cases, in that incomplete diversity of citizenship is usually what makes joinder impractical or impossible. See note 90 .

${ }^{43}$ The public rights exception states that when a party seeks to vindicate public rights (protection of the environment, for example) by suing a government agency, persons with private rights (polluters) affected by the disposition of the case are not necessary to the action. See National Licorice $v$ NLRB, 309 US 350, 363 (1940); Jeffries $v$ Georgia Residen- 
Nevertheless, in Shimkus $v$ Gersten Companies, ${ }^{44}$ the Ninth Circuit adopted the position that Rules 19 and 23 can work together and ordered the joinder of a necessary class. In the underlying litigation, Shimkus filed a civil rights class action on behalf of a group of African-Americans, charging that the defendant had specifically discriminated against them. A week later, the government filed suit against the defendants, charging them with housing discrimination against all minorities. The court in the government case entered a consent decree enjoining Gersten from discriminating against any minority. Eighteen months later, in the Shimkus case, the court entered a consent decree requiring Gersten to implement an affirmative action program specifically for AfricanAmericans. The Ninth Circuit held that the approval of the second settlement, which preferred African-Americans to the detriment of other minorities, was an abuse of discretion if rendered in the absence of the necessary class of non-African-American minorities. ${ }^{45}$ This result required the court to accept some interplay between Rule 19 and Rule 23. The court held that "Rule 19(d) simply requires us to respect the language of Rule 23, but allows joinder to the extent its use does not conflict with Rule 23's provisions." ${ }^{46}$ The court justified this interpretation of Rule 19(d) by focusing on the language of that section as it existed prior to its separation from 19(a) in 1966, rather than placing undue emphasis on the caption, "Exception of Class Actions."

The division in the courts over the legitimacy of necessary classes turns on how the courts read Rule 19(d). If Thompson is correct in its assumption that the language of the caption to Rule 19(d) controls, then courts would be mistaken to consider classes as "persons" necessary for a just adjudication. If, on the other hand, the language of the caption is not decisive, then the result in Shimkus is a legitimate resolution of the difficulties that arise when absentees are too numerous to join as individuals. Although Rule 19(d) is not so clear as to preclude either interpretation, Section III demonstrates that the interpretation adopted in Shimkus

tial Finance Authority, 678 F2d 919, 929 (11th Cir 1982); National Resources Defense Council v Berklund, 458 F Supp 925, 933 (D DC 1978); Carl Tobias, Rule 19 and the Public Rights Exception to Party Joinder, 65 NC L Rev 745, 765-69 (1987) (arguing that the courts have unjustifiably ignored Rule 19 in creating this exception).

« 816 F2d 1318 (9th Cir 1987).

45 Id at 1320 .

40 Id at 1321 (emphasis in original). Specifically, the court's emphasis on Rule 23's "provisions" suggests that the court looked beyond the word "exception" in the Rule's caption to the actual language of the rule. 
is both plausible and preferable in light of the policies underlying both Rules 19 and 23, their common history, and the inadequacies of the alternatives.

\section{Historical and Policy Arguments Supporting Recognition of the Necessary Class}

Rule 19(d) does not compel the conclusion that Rules 19 and 23 are mutually exclusive; that is, it does not declare that a class cannot be a person necessary for just adjudication. In fact, the language of section (d), when read in conjunction with the other Rules, suggests that section (d) simply obviates the need to join all class members once an adequate representative can be joined. Without the exception provided by Rule 19(d), a single defendant sued by a plaintiff class could move to require the joinder of all absent class members. ${ }^{47}$

The better reading of Rule $19(\mathrm{~d})$ is that once an adequate representative has been joined, Rule 23 makes it unnecessary to join those already represented even if they would otherwise be necessary under Rule 19(a). This is what is meant by Rule 19(d)'s requirement that the rest of the rule be applied "subject to the provisions of Rule 23." 48 A necessary class, then, is simply one that meets both the requirements of Rule 23 (a class) and Rule 19 (necessary to litigation).

The following three sections support this interpretation of Rule 19(d) by examining the historical development of the party joinder rules, their purposes, and the effectiveness of the available alternatives to the necessary class concept. The analysis which follows also provides some basis for appraising the scope and utility of necessary classes relative to other joinder mechanisms.

\section{A. The Historical Context}

The class action and the necessary parties rule share a common history in the courts of equity. This history clarifies the reasons for the adoption of Rule 19(d) in 1966 and sheds light on the proper interaction of Rules 19 and 23 today.

In the seventeenth and eighteenth centuries, the English courts of equity developed fairly workable necessary party rules. These rules arose in equity because Chancery afforded a greater

\footnotetext{
47 Charles A. Wright, Arthur R. Miller, and Mary Kay Kane, 7 Federal Practice and Procedure § 1626 at 363 (West, 2d ed 1986).

48 FRCP 19(d).
} 
opportunity for party joinder than did courts of law, in the interest of achieving "complete justice."49 This emphasis on a flexible and pragmatic approach to joinder in equity is a useful background for thinking about necessary classes and Rule 19(d) today. Professor Hazard summarized the English rules as follows:

1. All persons who are interested in a controversy are necessary parties to a suit involving that controversy, so that a complete disposition of the dispute may be made.

2. Joinder of necessary parties is excused when it is impossible, impractical, or involves undue complications.

3. A person who is not a party, unless represented by one who is a party, is not bound by a decree. ${ }^{50}$

These rules migrated to the American courts, became codified in the early state rules of procedure, ${ }^{61}$ and, with some changes, were embodied in Rule 19(a). In addition, the notion that some parties were "indispensable" and that a court should dismiss the action if it could not join them also developed in the late eighteenth century in England and the early nineteenth century in America. ${ }^{62}$ This concept survives today in Rule 19(b). ${ }^{53}$

These necessary party rules ultimately proved unsatisfactory, however, in cases with large numbers of such parties; the rise of such cases in the nineteenth century threatened the usefulness of the rules. These problems are illustrated by a passage from the $\mathrm{Su}$ preme Court's 1853 decision in Smith $v$ Swormstedt: ${ }^{54}$

40 Hazard, 61 Colum L Rev at 1268-75 (cited in note 1). For the development of the necessary party rules in the United States, see generally John W. Reed, Compulsory Joinder of Parties in Civil Actions, 55 Mich L Rev 327 (1957); Robert G. Bone, Mapping the Boundaries of a Dispute: Conceptions of Ideal Lawsuit Structure from the Field Code to the Federal Rules, 89 Colum L Rev 1 (1989). The Hazard article strongly influenced the drafters of the 1966 Amendments to Rule 19. See Proposed Amendments, 39 FRD at 90.

so Hazard, 61 Colum L Rev at 1255 (cited in note 1).

s1 See, for example, An Act to Simplify and Abridge the Practice, Pleadings and Proceedings of the Courts of this State (Code of Procedure), 1848 NY Laws 487, 497, 516. This Act, known as the Field Code, was a forerunner of the Federal Rules of Civil Procedure.

62 See Shields $v$ Barrow, 58 US (17 How) 130, 139 (1855) (the decision whether or not to proceed without non-diverse co-debtors turns on the question of whether their interest was "separable"). Later courts cited Shields's labelistic analysis of the necessary-indispensable doctrine with a myopic focus on the nature of the rights asserted rather than the practical considerations of individual cases. See Reed, 55 Mich L Rev at 355 (cited in note 49); Kaplan, 81 Harv L Rev at 359-62 (cited in note 13). But see Bone, 89 Colum L Rev at $65 \mathrm{n}$ 198 (cited in note 49) (sharply disagreeing with Hazard's account and attributing tensions in compulsory joinder to "deep-seated normative conflict, not doctrinal error").

63 The 1966 revision of Rule 19 (b) transformed the indispensable party concept into a more flexible notion and undid some of the legalism of earlier interpretations. See Provident Bank, 390 US at 124-25. See also Kaplan, 81 Harv L Rev at 362-66 (cited in note 13).

s4 57 US (16 How) 288 (1853). 
There are some fifteen hundred persons represented by the complainants, and over double that number by the defendants. It is manifest that to require all the parties to be brought upon the record, as is required in a suit at law [per the necessary parties rules], would amount to a denial of justice. The right might be defeated by objections to parties, from the difficulty of ascertaining them, or if ascertained, from the changes constantly occurring by death or otherwise. ${ }^{55}$

These practical difficulties led the courts of equity to adopt the class suit in which one member of a class was permitted "to 'stand for' all the class members for purposes of the necessary parties rule. This meant that the action could go forward without individual joinder of all members of the group." forerunner of the modern class action. ${ }^{57}$

Thus class actions, embodied in Rule 23, arose out of the historical need to circumvent the completeness requirement of the necessary parties rules, embodied in Rule 19. Read together in this light, Rule 19(d) can be seen as simply codifying that historical relationship. Section (d), then, relaxes Rule 19 joinder requirements for class members once the requirements of Rule 23 are satisfied and an adequate representative is joined. ${ }^{58}$ Rule 19(d) simply prevents a party from moving to compel the joinder of all class members in addition to their representative.

\section{B. The Policies Underlying the Party Joinder Rules}

The necessary class concept produced by the close relationship between Rule 19 and Rule 23 also finds support in the common

ss Id at 303.

se Fleming James, Jr. and Geoffrey C. Hazard, Jr., Civil Procedure § 10.21 at 563 (Little, Brown, 3d ed 1985). See also Chafee, Some Problems of Equity at 203-13 (cited in note 2); Rules of Practice for the Courts of Equity of the United States, 226 US 659 (1912) (Rule 38 , originally adopted by the Supreme Court in 1842 , provided that "[w] hen the question is one of common or general interest to many persons constituting a class so numerous as to make it impracticable to bring them all before the court, one or more may sue or defend for the whole.").

B7 The class action also has origins in the multiplicity of suits doctrine which enabled equity courts to obtain jurisdiction over a number of separate actions when there was no other basis for jurisdiction. See Bone, 89 Colum L Rev at 29 (cited in note 49). See generally Chafee, Some Problems of Equity at 156-58 (cited in note 2).

s8 See General Telephone Co. v Falcon, 457 US 147, 155 (1982) (recognizing the class action as an "exception to the usual rule that litigation is conducted by and on behalf of the individual named parties only"). 
purposes of the two rules. Rule 19 joinder serves four policy goals: (1) minimizing duplicative litigation; (2) protecting the interests of absentees; (3) protecting certain defendants; and (4) preserving judicial efficiency and integrity. ${ }^{59}$ Importantly, Rule 23 furthers the same policies. The class action furthers the first two policies cited above by involving those persons most likely to suffer some impairment of interest as a result of the litigation. This involvement conserves judicial resources and minimizes the risk of trampling upon the interests of absentees by granting a remedy that, although not legally binding on the absentees, disposes of the matter for all practical purposes. ${ }^{60}$

Rule 23 also serves the third and fourth policy goals by reducing the incidence of multiple, inconsistent obligations arising from separate judgments against the defendant. In Shimkus, for example, the housing preferences secured by the African-American class conflicted with the decree already entered on behalf of the nonAfrican-American minority classes. The non-African-American minorities were now doubly disadvantaged by the special treatment afforded the African-Americans in the competition for housing. ${ }^{61}$ Not only did this burden the defendant with the additional suits, but it raised the specter of even more litigation to untangle potentially incompatible judgments. This additional litigation would not only be expensive, but the appearance of schizophrenia and caprice would demean the law in the eyes of the public. ${ }^{62}$

\section{The Inadequacy of Alternative Solutions}

A number of other procedural solutions exist to protect absentee parties. Of these, intervention of right under Rule 24 is the most effective such mechanism. The other alternatives include shaping the relief available to the plaintiff to protect the absen-

so See Freer, 60 NYU L Rev at 1079 (cited in note 11). See generally John C. McCoid, A Single Package for Multiparty Disputes, 28 Stan L Rev 707, 707 (1976); Richard D. Freer, Avoiding Duplicative Litigation: Rethinking Plaintiff Autonomy and the Court's Role in Defining the Litigative Unit, $50 \mathrm{U}$ Pitt L Rev 809, 813 (1989).

- This emphasis on practical effects, rather than purely legal consequences (res judicata), is an innovation of the 1966 amendments. This emphasis is also reflected in the changes to Rules 19(b) and 24(a). See Kaplan, 81 Harv L Rev at 365, 402, 405 (cited in note 13).

816 F2d at 1321.

62 See McCoid, 28 Stan L Rev at 707 (cited in note 59) ("The specter of public dismay over a system that decides like cases differently is a disturbing one."). 
tees, ${ }^{63}$ holding fairness hearings as a prerequisite to the approval of consent decrees, ${ }^{64}$ consolidating multiple actions, ${ }^{65}$ requiring that absentees be given notice, ${ }^{66}$ allowing collateral attack by the absentee class, ${ }^{67}$ or simply ignoring the absentee class interests. ${ }^{68}$ Each of these provisions, however, leaves third parties wholly or partly unprotected. Allowing joinder of necessary classes would provide this lacking protection.

Intervention, particularly if combined with some type of notice provision, offers some advantages over necessary classes. Above all, intervention does not require joinder. Rather, it encourages the absentee to join a suit only when the absentee thinks it worth the effort. ${ }^{69}$ In this respect, intervenors are self-regulating and require no procedural hammers or judicial involvement to ensure their participation. Joinder of parties under Rule 19, on the other hand, must be initiated by the plaintiffs or defendants. Moreover, because the intervenor's effort to participate indicates a powerful interest in the case, the standard for asserting a significant interest under Rule 24(a), while technically the same as the standard under Rule $19(\mathrm{a}),{ }^{70}$ may be weaker. ${ }^{71}$ In fact, it is com-

ss See FRCP 19(b).

34 See Laycock, 1987 U Chi Legal F at 121-24 (cited in note 19).

8s See 28 USC $\$ \S 1406-1407$ (1990). Section 1406 provides that "in the interests of justice," a district court can transfer a case in which venue is improper to a district in which the case could have been brought. Section 1407 establishes a procedure for multi-district litigation. See also, Kramer, 87 Mich L Rev at 335-38 (cited in note 24) (arguing that transfer and consolidation under Rule 42 is preferable to Rule 19 joinder of absentees potentially affected by a consent decree).

as This might be accomplished either under FRCP 23(d), "for the fair conduct of the action," or possibly by amending the provisions of FRCP 19(c).

${ }^{87}$ See, for example, Martin $v$ Wilks, 490 US 755, 762-63 (1989).

83 See generally Laycock, 1987 U Chi Legal F at 130-31 (cited in note 19) (though consent decree between litigants may require joinder of absentees under Rule 19, "[t]he rule appears to be more ignored than followed"); Kramer, 87 Mich L Rev at 342 (cited in note 24) (even where absent third parties not denied due process, courts have sometimes treated them "unfairly").

69 See Freer, 60 NYU L Rev at 1086 (cited in note 11).

${ }^{70}$ Compare FRCP 24(a)(2) (allowing intervention "when the applicant claims an interest relating to the property or transaction which is the subject of the action and the applicant is so situated that the disposition of the action may as a practical matter impair or impede the applicant's ability to protect that interest, unless the applicant's interest is adequately represented by existing parties"), with FRCP 19(a)(2) (requiring joinder unless "the person claims an interest relating to the subject of the action and is so situated that the disposition of the action in the person's absence may (i) as a practical matter impair or impede the person's ability to protect that interest ....").

${ }^{71}$ Nuesse v Camp, 385 F2d 694, 700 (DC Cir 1967); James and Hazard, Civil Procedure $\S 10.17$ at 553 (cited in note 56 ). 
mon practice to allow both intervention of right and permissive intervention of classes. ${ }^{\mathbf{2 2}}$

However, intervention does not always support the four policy goals of Rule 19. Rule 24 does not swallow Rule 19. The fact that the Federal Rules separately provide for intervention and necessary parties suggests that Rule 19 handles cases that Rule 24 does not. There are situations, for example, in which the interest in joining the absentees is sufficiently compelling to draw them into the litigation even if they do not wish to join. Also, absentees may be unsophisticated or otherwise unaware of the original litigation. Moreover, even if they do appreciate the threat, they may not be in a position to defend their interests adequately. ${ }^{73}$

Because intervention relies on action by the absent parties, the interests of both the court and the defendant are jeopardized as well. Members of the absent class can sue later, seeking relief contrary to that awarded in the first action. ${ }^{74}$ This potential for incompatible obligations increases the likelihood that future litigation will be necessary to reconcile the competing judgments. It also risks putting the defendant in the unfortunate position of trying to satisfy inconsistent obligations. Thus, even if intervention and notice are sufficient to protect absentees, the court's and the defendant's interests ${ }^{75}$ should still lean in favor of allowing joinder of necessary classes.

\section{The Scope and Utility of the Necessary Class}

The concept of the necessary class, as demonstrated above, is supported both by the history of Rules 19 and 23, and by their common policy goals. Still, questions remain concerning its implementation in actual practice and its utility in comparison with other possible alternatives. Necessary classes, for example, may compromise the settlement options available to the original litigants. ${ }^{76}$ They raise questions of who ought to identify absent par-

${ }^{72}$ See, for example, Jansen $v$ City of Cincinnati, 904 F2d 336, 344 (6th Cir 1990) (class of African-American applicants permitted to intervene as a matter of right under Rule 24(a) in a civil rights action filed by white applicants). See also Payne $v$ Weirton Steel Co., $397 \mathrm{~F}$ Supp 192, 196 (N D W Va 1975) (class of women employees permitted to intervene under Rule 24(b) and join plaintiffs' class in discrimination suit against employer).

${ }^{73}$ McCoid, 28 Stan L Rev at 714 (cited in note 59). Adding a notice requirement to Rule 19(c) might alleviate the problems that result from the absentees' lack of awareness, but it would not overcome their inability to act.

" See, for example, LCC Corp. v PBGC, 94 FRD 15, 17 (E D Mo 1980).

73 See Freer, 60 NYU L Rev at 1094-95 (cited in note 11).

${ }^{76}$ Defendant class actions provide a useful comparison. In a defendant class action, a plaintiff seeks resolution of claims against a large number of defendants by naming a member of the defendant class as a representative of all defendants. Like the necessary class 
ties, who ought to pay for notice to such parties, and who ought to represent them. ${ }^{77}$ Moreover, necessary classes impose more burdens on an already overburdened judiciary. This section examines these difficulties, which judges should recognize as limits on the utility of necessary classes. It then focuses on the three types of class actions authorized in Rule 23 in an effort to discern the scope of necessary classes.

\section{A. Difficulties with the Rule 19 Solution}

Rule 19 is not without its own practical difficulties and is not a panacea for situations inadequately addressed by other alternatives. The provisions adopted by the Federal Rules to effect joinder are inadequate to attain fully the purposes underlying joinder. Allowing necessary classes may also encourage inefficient strategic behavior by defendants. Courts should be advised of the availability of the necessary class device, but should also be aware of these difficulties.

Though joinder of necessary parties is desirable, the mechanisms ${ }^{78}$ adopted by the Federal Rules to achieve it are sometimes ineffective. ${ }^{79}$ Rule $19(\mathrm{c})$, for example, requires that the plaintiff join all necessary parties or state their names in the pleading along

device, defendant class actions impose additional burdens on an unwilling group, namely the defendant. The necessary class is also somewhat different, however, in that all of its members are absent from the original litigation. This complete absence makes it more difficult to recognize that the class exists at all, and exacerbates the problems of the unwilling class representative. Necessary classes, unlike defendant class actions, also raise questions of who should bear the costs of notifying and representing these additional litigants, and constrain the original litigants' interests in resolving their bilateral conflict quickly and economically. See generally Note, Defendant Class Actions, 91 Harv L Rev 630 (1978); Note, Certification of Defendant Classes Under Rule 23(b)(2), 84 Colum L Rev 1371 (1984); Note, Defendant Class Certification: The Difficulties Under Rule 23(b)(2) and the Rule 65(d) Solution, 8 NIU L Rev 143 (1987); Comment, 38 UCLA L Rev 223 (cited in note 20); Herbert B. Newberg, 1 Newberg on Class Actions §§ 4.45-4.70 at 373-421 (McGraw-Hill, 2d ed 1985).

${ }_{77}$ If the absent class is necessary and ought to be joined as a defendant, the court should be able to manage the adequacy of representation by (1) not allowing the action to proceed without the class, and (2) not allowing it to proceed as a class action unless the plaintiff joins an adequate representative from the necessary class. See FRCP 23(d); Newberg, 1 Newberg on Class Actions \$ 4.58 at 399 (cited in note 76) (discussing the court's ability to impose conditions on class actions to ensure that the plaintiff does not select a weak representative for a defendant class).

${ }^{78}$ These are the pleading requirements of FRCP 19(c), the defendant's motion to dismiss under FRCP 12(b)(7), and the court's motion to dismiss sua sponte. See Kaplan, 81 Harv L Rev at 374 (cited in note 13).

70 Freer, 60 NYU L Rev at 1082 (cited in note 11); McCoid, 28 Stan L Rev at 75 (cited in note 59). 
with reasons for nonjoinder. ${ }^{80}$ However, unless the plaintiff and his counsel seek to represent a plaintiff class, or seek to sue a vulnerable defendant class, they have no incentive to complicate the litigation and frustrate their own potential for success by joining other interested parties. ${ }^{81}$

A more important enforcement mechanism is Rule 12(b)(7), which provides for dismissal for failure to join a Rule 19 party. Unfortunately, this mechanism is too often ineffective. ${ }^{82}$ Defendants are unlikely to invite hostile classes into the litigation (which is akin to awakening a sleeping giant), thereby multiplying their potential liability, unless they face an almost certain risk of imminent conflicting obligations and cannot interplead the potential claimants. ${ }^{83}$ Similarly, it is not clear that the defendant would wish to risk attracting the attention of the currently sleeping class by making a Rule $12(\mathrm{~b})(7)$ motion to dismiss. A court may also raise the issue of absent but necessary parties on its own motion, but courts do so infrequently. ${ }^{84}$ Moreover, since misjoinder is a procedural policy issue and not a jurisdictional defect, a judgment rendered in a necessary party's absence is not open to collateral attack in a subsequent action by that party. ${ }^{85}$

These criticisms, of course, apply to the general ineffectiveness of Rule 19 in joining necessary parties, not solely to its ineffectiveness in the class action context. Although this Comment does not

so FRCP 19(c) provides: "A pleading asserting a claim for relief shall state the names, if known to the pleader, of any [necessary persons] who are not joined, and the reasons why they are not joined."

81 See James and Hazard, Civil Procedure § 10.12 at 535-38 (cited in note 56).

82 Freer, 60 NYU L Rev at 1079-80 (cited in note 11) (because, as a practical matter, Rule 19 nonjoinder is only invoked by the defendant, the absentee and society's interests are subject to his litigation strategy).

${ }^{83}$ Id.

24 See McCoid, 28 Stan L Rev at 727-28 n 129 (cited in note 59) (judges should seek to join claims in a single "package" more frequently). But see Freer, 60 NYU L Rev at $1079 \mathrm{n}$ 96 (cited in note 11) (judges are in a poor position to raise the issue, especially given general disuse of Rule 19(c)).

8s See Provident Bank, 390 US at 116 (Since Rule 19(b) is based on policy considerations such as the efficiency of resolving claims in a single proceeding, misjoinder is less problematic at later stages of the litigation: "By the time the case reached the Court of Appeals, however, the problematic preference on efficiency grounds had entirely disappeared: there was no reason then to throw away a valid judgment just because it did not theoretically settle the whole controversy."). The earlier judgment is not legally binding against the absentee in a subsequent action, but it may be preclusive in a practical sense. See also Kaplan, 81 Harv L Rev at 366 (cited in note 13) ("disappearance of the bugaboo of jurisdiction"); Wright, Miller and Kane, 7 Federal Practice and Procedure $\$ 1611$ at 178 (cited in note 47) ("not subject to collateral attack in a subsequent action since ... the defect is not jurisdictional"). 
attempt to rectify all of the problems associated with Rule 19, the above discussion does raise an important issue specific to the necessary class context. An expansive interpretation of the existing rules would go a long way to solving this one specific problem.

Joinder of necessary parties requires the judiciary to take an active role in protecting absent claimants and the public. Judges must be attentive to those cases where the class of absentees possesses an interest subject to substantial impairment under Rule 19(a)(2)(i). In the class action context, the necessity of an alert judiciary is even greater. The class action is quite commonly used in areas like civil rights or environmental litigation in which the absentees' lack of sophistication and their inability to afford legal counsel $^{86}$ may have prevented their intervention in the first place.

Courts should also be aware that defendants might find the necessary class a potent weapon against plaintiffs. Defendants have the greatest incentive to raise the issue of absent classes when the absent class would be certified as a codefendant. Because the claimants would bear the initial burden of notice costs, ${ }^{87}$ the joinder of a new defendant class may deter litigation of the claims. ${ }^{88}$ More importantly, the additional defendant class probably will provide litigation support to the defendants and offer little in the way of potential relief for the plaintiff. ${ }^{89}$ Thus, allowing joinder of a necessary class in some instances may perversely increase the incidence of strategic behavior. ${ }^{90}$

In summary, Rule 19(d) does not preclude joinder of a necessary class, but use of a necessary class does raise some practical considerations. Judges must be aware of those circumstances in

ss The absentees may not be able to afford legal representation for a variety of reasons: they may be poor; their prospects of prevailing may be speculative; or the value of the requested relief-usually an injunction-may be low.

${ }^{87}$ Eisen v Carlisle \& Jacquelin, 417 US 156, 178 (1974); Meadows v Ford Motor Co., 62 FRD 98, 101-02 (W D Ky 1973).

${ }^{8 s}$ Compare Note, 91 Harv L Rev at 647-50 (cited in note 76).

88 A successful judgment against a class of impecunious defendants may not be worth the effort required to collect it.

?o The fact that federal courts are courts of limited jurisdiction may offset the potential harm to the plaintiff. In Strawbridge v Curtiss, 7 US (3 Cranch) 267 (1806), the Supreme Court held that federal courts obtain diversity jurisdiction over a case only if all parties to the action are diverse. As a result, if a defendant can identify a necessary party who is nondiverse, he can compel joinder of that party and force the case into state court. Allowing joinder of necessary classes may provide a solution to this difficulty. Under Supreme Tribe of Ben-Hur v Cauble, 266 US 356, 367 (1921), only the class representative must be diverse. Therefore, if the plaintiff can locate a person in the same situation as the non-diverse necessary party, but who is diverse, the plaintiff can join the necessary individuals as a class with the diverse person as the class representative, and retain the court's diversity jurisdiction. 
which a truly necessary class is lacking, and also of those circumstances in which a necessary class is not really "necessary," but is joined for purely strategic reasons.

\section{B. Scope of the Necessary Class}

A further issue raised by the interplay of Rules 19 and 23 is the question of which Rule takes precedence in determining the existence of a necessary class. Must the class be of a special type under Rule 23(b), or does the standard in Rule 19(a) control? In this section, the Comment argues that Rule 19(a) determines the necessity of joining the class (regardless of how Rule 23 would categorize that class). But, of course, the class must also meet Rule 23 's prerequisite and type requirements.

Briefly, for a class to be necessary for a just adjudication, it must meet the standards of Rule 19(a). This means that, in addition to satisfying the requirements of Rule 23(a), the class must also qualify as a Rule $23(\mathrm{~b})(1)$ or Rule $23(\mathrm{~b})(2)$ class. Since Rule 23(b)(3) "common question" classes are certified to permit (but not require) the joinder of legally unrelated claims, they cannot be necessary unless they also qualify as Rule 23(b)(1) or Rule 23(b)(2) classes. Rule 23(b)(1) "mandatory classes" essentially consist of Rule 19 parties and can be necessary to an already existing bilateral suit. More problematic, however, are Rule 23(b)(2) "injunctive class actions." Nevertheless, because courts have interpreted Rule 23(b)(1) more narrowly than similar language in 19(a)(2), there will still be some situations where Rule 23(b)(2) classes will be necessary classes under Rule 19. In any event, the key requirement is that the class qualifies as necessary under Rule 19(a). It is irrelevant for these purposes whether the class is a Rule 23(b)(1) class, a Rule 23(b)(2) class, or a Rule 23(b)(3) class, so long as it is one of these.

The Rule 23(b)(1) mandatory class action provides for certification of a class where separate actions by the members of the class could result in "inconsistent or varying adjudications . . . which would establish incompatible standards of conduct for the party opposing the class" or adjudications that would "impair or impede" the ability of non-party class members to protect their interests. In other words, a class certified under Rule 23(b)(1) is simply a group of Rule 19 necessary parties, analogous to equity's old representative suit. ${ }^{91}$ The close relationship between the neces-

"2 Robinson v First National City Bank, 482 F Supp 92, 98 n 14 (S D NY 1979); FRCP 23, Advisory Committee Note (referring to FRCP 19(a)(2)(i) and (ii)). 
sary parties rule and the $23(b)(1)$ class is illustrated when one compares the two prongs of Rule 19(a)(2) with those of Rule 23(b)(1). Both Rules note the risk of multiple, inconsistent obligations and the risk that an adjudication will impair the interests of absentees as the factors to consider when deciding whether the respective rule applies. Moreover, the Advisory Committee Notes state that the two rules were drafted with similar interests in mind. ${ }^{\mathbf{2}}$

Despite their textual similarity, the overlap between Rule 19(a)(2) and Rule 23(b)(1) may not be complete. Courts tend to interpret the requirements of the Rule 23(b)(1) mandatory class action in accordance with pre-1966 Rule 19 standards. ${ }^{93}$ Thus Rule $23(b)(1)$ actions often turn on whether the class members are "united in interest" in a legal sense. This standard differs from that of Rule 19(a) which, since 1966, also considers practical risks when determining whether a person is a necessary party. In other words, even if a class does not qualify as a "mandatory class" under the technical legal standard of Rule 23(b)(1), it may still qualify as a necessary class. To be a necessary class, however, the group must still be certifiable under Rule 23(b)(2) (or much less likely, under Rule 23(b)(3)), and meet the requirements of Rule 19(a) and 23(a).

A Rule 23(b)(3) "common question class action" depends on the predominance of a common question of law or fact. It has no analog in Rule 19. Rule 23(b)(3) evolved out of the multiplicity of suits doctrine which allowed for class suits by groups of people who had unrelated, but essentially identical claims. ${ }^{94}$ The goal of the doctrine was to reduce administrative costs and to streamline litigation by resolving factually similar cases in a single action. ${ }^{98}$ Since the "common question class action" represents an example of permissive joinder and depends more on considerations of convenience, it is unlikely to implicate Rule 19 and require joinder unless the class also qualifies as a Rule $23(b)(1)$ or Rule 23(b)(2) class.

${ }^{92}$ Proposed Amendments, 39 FRD at 100.

93 See Newberg, 1 Newberg on Class Actions $\$ 4.63$ at 407 (cited in note 76) (discussing mutuality of estoppel and similarity of new Rule 23 to the old rule), $\S 4.04$ at 275-79 (discussing judicial efforts to limit the scope of Rule 23(b)(1)).

24 See note 57 and accompanying text.

9s A class member can elect to opt out of a Rule 23(b)(3) class, but not out of a Rule 23(b)(1) or Rule 23(b)(2) class. Van Gemert v Boeing, 259 F Supp 125, 130-31 (S D NY 1966); Newberg, 1 Newberg on Class Actions $\S 4.20$ at 311-12 (cited in note 76). See generally Chafee, Some Problems of Equity at 152 (cited in note 2). 
Lastly, Rule 23(b)(2) injunctive class actions are the most problematic of the three types of class actions for purposes of this Comment. They are class actions where the injunctive relief requested would affect all the class members, as is frequently the case in civil rights litigation. There is no analog for this provision in Rule 19(a). However, situations in which a class is certified under Rule 23(b)(2) may overlap with circumstances in which joinder of a necessary party is appropriate: where the ability of the absentees to protect their interests is impaired or where the risk of multiple, inconsistent obligations against the defendant is apparent. This does not mean, however, that an injunctive class action must also qualify as a Rule $23(\mathrm{~b})(1)$ mandatory class action to come under Rule 19(a). As discussed above, although Rule 19(a)(2) and the Rule 23(b)(1) class action focus on the same factors, the standards under which those factors are examined differ. ${ }^{96}$ Because the two are not wholly congruent, there may be situations in which a class that qualifies as a Rule 23(b)(2) "injunctive class action," but not as a Rule 23(b)(1) "mandatory class action," may still be a necessary party under Rule 19(a). ${ }^{97}$

Because necessary classes are akin to defendant classes in that both require the joinder of a large number of perhaps unwilling litigants, ${ }^{98}$ the availability of Rule 19 to Rule 23(b)(2) classes may also depend on whether a Rule 23(b)(2) class can be a defendant class. If so, this is an objection to the existence of Rule 23(b)(2) necessary classes. Several courts and commentators, citing the significant costs and complexities associated with defendant class actions, have taken a narrow view of defendant class actions when certified as "injunctive class actions" under Rule $23(\mathrm{~b})(2){ }^{99}$ The main objection is that the language of Rule $23(\mathrm{~b})(2)$ suggests that it is appropriate only where injunctive relief benefits the class, not the party opposing the class. This interpretation stymies injunctive defendant class actions, but does not pose as significant a barrier

\footnotetext{
96 See note 93 and accompanying text.

"7 See Shimkus, 816 F2d at 1322 (non-African American minorities' ability to protect interest in remedying housing discrimination is impeded and impaired by nonjoinder).

- See discussion of defendant classes in note 76.

- See Comment, 38 UCLA L Rev at 228-34 (cited in note 20). Compare Henson v East Lincoln Township, 814 F2d 410, 413-17 (7th Cir 1987); Thompson $v$ Board of Education of Romeo Community Schools, 709 F2d 1200, 1204 (6th Cir 1983) (Rule 23(b)(2) does not contemplate certification of a defendant class); Paxman v Campbell, 612 F2d 848, 854 (4th Cir 1980) (allowing certification of defendant class creates an "anomalous situation"), with Marcera $v$ Chinlund, 595 F2d 1231, 1238-39 (2d Cir 1979) (Rule 23(b)(2) can be used to certify a defendant class of public officials), vacated on other grounds, Lombard v Marcera, 442 US 915 (1979).
} 
for necessary classes, whose interests might be protected by injunctive relief. ${ }^{100}$ Necessary classes may have a stronger case, moreover, in that without some representation in the litigation their interests will be affected in their absence. At least in the ordinary defendant class action the original defendant offers some protection even if the court refuses to certify a class.

\section{Conclusion}

The joinder of necessary classes under Rule 19 is an important mechanism for the protection of absent classes. Rule 19(d) does not impede, but rather encourages, the joinder of classes where they are necessary for a just adjudication. Section (d)'s purpose, as illuminated by historical and policy considerations, is simply to obviate the need in any class action to join all absent class members once an adequate representative has been joined. This provision preserves the utility of the class action as a device for convenient and efficient adjudication. Indeed, Rule 19 is a superior mechanism where disputes concerning several classes threaten to impair the interests of unsophisticated groups of absentees, and may also offer an end-run around diversity problems created by Rule 19(b).

${ }^{100}$ See, for example, Shimkus, 816 F2d at 1322. 